\title{
High prevalence of cardiovascular risk factors in Gerona, Spain, a province with low myocardial infarction incidence
}

Rafel Masiá, Araceli Pena, Jaume Marrugat, Joan Sala, Joan Vila, Marco Pavesi, Maribel Covas, Clara Aubó, Roberto Elosua and the REGICOR Investigators

\begin{abstract}
Study objective-To establish the prevalence of main cardiovascular risk factors in the province of Gerona, where the incidence of myocardial infarction is known to be low.
\end{abstract}

Design-This was a cross sectional study of prevalence of cardiovascular risk factors conducted on a large random population sample.

Setting-The province of Gerona, Spain. Participants-Two thousand four hundred and four eligible inhabitants of Gerona aged between 25 and 74 years were randomly selected for a multi-stage sample stratified by age and sex. The following were standardly measured: lipids (total cholesterol, high density, low density, lipoprotein (a) and triglycerides), fibrinogen, basal glycaemia, arterial pressure, anthropometric variables, smoking, history of angina (Rose questionnaire), and a medical history questionnaire. Population measurements were standardised for the world population of 24 to 74 years of age.

Results-The participation rate was $72.7 \%$ (1748). Total mean cholesterol was 5.69 $\mathrm{mmol} / 1$ in men and $5.61 \mathrm{mmol} / 1$ in women and mean high density cholesterol was $1.22 \mathrm{mmol} / 1$ and $1.47 \mathrm{mmol} / 1$, respectively. Median lipoprotein (a) was $0.22 \mathrm{~g} / 1$. These three lipids increased significantly with age. Mean fibrinogen was $2.92 \mathrm{~g} / 1$ in men and $3.09 \mathrm{~g} / 1$ in women, and was higher in smokers. The prevalence of hypertension (systolic arterial tension $\geqslant 140 \mathrm{~mm} \mathrm{Hg}$ or diastolic $\geqslant 90 \mathrm{~mm} \mathrm{Hg}$ or drug treatment) was $31.3 \%$ in men and $27.7 \%$ in women. The proportion of male smokers was $33.8 \%$ and female smokers $22.7 \%$. The proportion of female smokers in the 25-34 year age group exceeded that of the remaining age groups for both men and women.

Conclusions-The prevalence of cardiovascular risk factors in Gerona is relatively high for the low myocardial infarction incidence typical of the area, although similar to that of other Spanish areas. The factors that confer sufficient protection to compensate for the effect of the prevalence of these risk factors remain to be elucidated.

(F Epidemiol Community Health 1998;52:707-715)
To be able to explain the behaviour of the incidence, mortality and morbidity of cardiovascular diseases (CVD), it is necessary to know the distribution and frequency of determining factors.

CVD, particularly ischaemic coronary diseases (ICD) continue to be the main cause of death in Spain. In 1993, ICD represented a total of 20785 deaths in men (11.6\% of overall mortality) and 15280 in women (9.6\%). Furthermore, ICD produce high morbidity in Spain: the cumulated incidence rate of acute myocardial infarction (AMI) in 1990-1992 per 100000 inhabitants and year, standardised for age, in the 25-74 age group was 207.5 in men and 48.5 in women. ${ }^{2}$ Estimations of the prevalence of classic cardiovascular risk factors (CRF) have been made in Spain in population samples from various communities ${ }^{3-5}$ and groups of workers. ${ }^{6}$ These studies, despite being well designed and conducted, differ in the measurement methods used, which jeopardises their comparability. Moreover, studies in populations whose ICD incidence is known ${ }^{2}$ and can be put into perspective with the prevalence of CRF are scarce. It is therefore recommended to measure CRF using well standardised methods that facilitate national and international comparability, preferably in areas where the incidence of some presenting form of ICD, generally AMI is known.

The aim of this study was to establish the prevalence of CRF in a well defined population comprising six regions of Girona. This study area is known to have low AMI incidence and death rates, ${ }^{2}$ which permits also the exploration of whether this is associated with low CRF levels in the population.

\section{Methods}

SAMPLE

A cross sectional study was designed with a two stage population random sample stratified in five age groups (25-34, 35-44, 45-54, 55-64, and 65-74 years) and sex. A sample size of 2400 participants was sought to allow for a statistical power greater than $80 \%$ to detect as statistically significant in a two sided test $(p<0.05)$ differences of 15 per cent units between strata in a categorical variable when the prevalence in any of the strata is $30 \%$.

The reference population was composed of six regions of the province of Gerona comprising 189 towns and 509618 inhabitants according to the 1991 census, of whom 256604 were women and 253014 men. The 25 to 74 age 
group included 152150 men and 151753 women. ${ }^{7}$ Approximately half the population lived in towns of more than 10000 inhabitants.

In a pilot study it was estimated that the proportion of censal errors, deaths, those temporarily absent or institutionalised was approximately $20 \%$; the 2400 people sample was therefore increased up to 3000 subjects to replace non-eligible candidates. The study was conducted between September 1994 and January 1996.

Thirty three towns were randomly selected in the first phase of the study. Eight of these, considered urban, had more than 10000 inhabitants and comprised half of the total sample. The remainder were towns of between 500 and 10000 inhabitants, considered rural. Selected people were notified in their own towns by a letter informing them of the aims of the study. The tests to be performed were also described and participants were requested to attend the health examination in a fasting state of at least 14 hours; a telephone number for inquiries was supplied. If the participants had a phone, they were contacted one week before the examination to confirm their attendance. Examinations were performed by a physician, two nurses, and two auxiliaries who went to all the participating towns in teams composed of the physician (always the same), a nurse, and an auxiliary.

\section{REGISTERED VARIABLES}

\section{Anthropometric measurements}

A precision scale of easy calibration was used for weight measurement. Participants wore underwear. Height was also measured. Body mass index (BMI) was determined as weight divided by squared height $\left(\mathrm{kg} / \mathrm{m}^{2}\right)$. Standardised measures of waist and hip perimeter were performed. The quotient between both measurements constitutes the waist/hip index.

Measurement of the tricipital skin fold of both arms was taken with three consecutive measurements in each arm. The arithmetic mean of the three determinations was used for the analysis.

\section{Electrocardiogram}

A standard 12-lead electrocardiogram recording was obtained for each participant. Minnesota code was applied to assess the result. ${ }^{8}$ The proportion of participants with definite (codes 1.1.1 to 1.1.7) or possible (codes 1.2.1 to 1.2.8) AMI is presented.

\section{Blood pressure}

Blood pressure (BP) determination was made using a periodically calibrated mercury sphygmomanometer. The operator followed a certification process in the standardised measurement technique at central laboratory and all determinations were always made by the same person. A cuff adapted to upper arm perimeter (young, adult, obese) was selected for each participant. Measurements were performed after a five minute rest. Two measurements were taken: the interval between the first and second was at least 20 minutes. The value used was the arithmetic mean of both determinations.

\section{Laboratory analyses}

Total cholesterol, high density lipoprotein cholesterol (c-HDL), triglycerides, low density lipoprotein cholesterol (c-LDL), lipoprotein (a) $(\operatorname{Lp}(\mathrm{a}))$, basal glycaemia and fibrinogen were analysed.

Extractions were made after a 14 hour fast without venous compression (or less 60 seconds duration when strictly necessary) using a syringe with a holder and vacuum tubes with separating gel. Extraction with citrate was also made for fibrinogen analysis. Samples were centrifuged between 30 and 60 minutes after extraction and the serum samples immediately frozen at $-120^{\circ} \mathrm{C}$ in liquid nitrogen, and transported within seven days to a refrigerator set at $-80^{\circ} \mathrm{C}$ for definitive conservation. Analyses were performed at an interval of three to four months after extraction in groups of 600 samples.

Total cholesterol and triglycerides concentrations were determined enzymatically (Roche Diagnostica, Basel, Switzerland). c-HDL was measured as cholesterol after precipitation of apoprotein B containing lipoproteins with phosphotungstic- $\mathrm{Mg}^{++}$(Boehringher Mannheim, Mannheim, Germany). Serum Lp(a) was determined by an immunoturbidimetric method (Immunoturb Lp(a), Immuno Diagnostica, Vienna, Austria). ${ }^{9}$ Analyses were performed in an Cobas Mira Plus (Roche Diagnostica, Basel Switzerland). Plasma fibrinogen concentration was determined by a coagulometric method in a coagulometric autoanalyser (Toe Medical Electronics Co, LTD, Kobe, Japan). External quality assessment was performed with External Quality Assessment-WHO Lipid Program (World Health Organisation, Prague, Czech Republic) and Monitrol-Quality Control Program (Baxter Diagnostics, Dudingen, Switzerland). Interassay coefficients of variation were $2.5 \%, 4.5 \%$, and $3.2 \%$ for total cholesterol, HDL cholesterol, and triglycerides, respectively. In $\mathrm{Lp}$ (a) concentrations of $0.26 \mathrm{~g} / 1,0.70 \mathrm{~g} / \mathrm{l}$, and 1.22 $\mathrm{g} / \mathrm{l}$, respectively were used. c-LDL was calculated by the Friedewald equation.

\section{QUESTIONNAIRES}

Demographic characteristics, personal history of diabetes mellitus (DM) and ICD were recorded by inquiry.

\section{Hypertension questionnaire}

The hypertension questionnaire of the MONICA-WHO ${ }^{10}$ study was used, in which participants were asked whether any healthcare personnel had informed them that their BP was high and whether they had taken any control medication in the previous two weeks. From these data and the BP found during the examination, the participants were classified as: I, controlled hypertension: SBT $<160$ and DBT $<95 \mathrm{~mm} \mathrm{Hg}$ in those with drug treatment; II, non-controlled hypertension: SBT $\geqslant 160$ and/or DBT $\geqslant 95 \mathrm{~mm} \mathrm{Hg}$ in those with drug treatment; 
III, observed hypertension: SBT $\geqslant 160$ and/or DBT $\geqslant 95 \mathrm{~mm} \mathrm{Hg}$ in those not treated; IV, normotensive: SBT $<160$ and DBT $<95 \mathrm{~mm} \mathrm{Hg}$ in those not treated; V, real hypertension: I + II + III.

On the other hand, with the aim of facilitating comparability of hypertension rates with more modern criteria, those recently published by the Joint National Committee on detection, evaluation and treatment of high blood pressure were used. ${ }^{11}$ The categories are the same as before using as a cut off point values of 140 and $90 \mathrm{~mm} \mathrm{Hg}$.

Smoking questionnaire

The questionnaire applied in the study consisted of eight questions regarding current and past cigarrette consumption including daily amount. ${ }^{10}$

\section{Angina questionnaire}

The World Health Organisation (WHO) recommends the use of Rose's WHO Questionnaire ${ }^{12}$ to determine the prevalence of angina in epidemiological studies. This questionnaire was administered by trained interviewers. Participants were classified as having definite angina, possible angina, non-exertional chest pain, and no chest pain. ${ }^{12}$

\section{Leisure time physical activity assessment}

The Minnesota leisure time physical activity questionnaire was used to assess the amount of leisure time physical activity performed during the previous year. ${ }^{13}$ This questionnaire has been validated for use among Spanish men. ${ }^{14}$ The questionnaire was administered by a trained interviewer.

ETHICAL ASPECTS

All participants were duly informed and consented to be entered in a computer data-base and cede their biological samples for the necessary analyses. The study design was approved by an ethics committee and the results sent to participants.

\section{STATISTICAL ANALYSIS}

To facilitate comparisons between local and international communities studies, prevalence results of each risk factor are presented by sexes in each 10 year age group for the 25 to 74 year interval, weighed according to the age distribution of the origin population ${ }^{7}$ and standardised by the world population ${ }^{15}$ in the $25-74$ and 35-64 year intervals. Continuous variables are presented as mean and standard deviation and categories as proportions.

In the case of $\operatorname{Lp}(\mathrm{a})$, which follows a distribution that clearly departs from normal, data are described using the median and minimum and maximum values.

The Mantel-Haenszel $\chi^{2}$ test was used to assess the linear trend of the prevalence of different risk factors in the defined age and sex groups.

Pearson's correlation coefficient was used to assess the strength of the association between each couple of continuous variables (for example, age and total cholesterol).
The Student $t$ test or one way analysis of variance were used to compare means of continuous variables between two or more categories (sex or age groups), respectively.

\section{Results}

Of the 3000 subjects selected, 596 (19.9\%) were not eligible because of errors in census data in $379(63.6 \%), 97(16.3 \%)$ were institutionalised, $83(13.9 \%)$ were temporally absent, and $40(6.7 \%)$ had died before the study was conducted. The final sample was therefore composed of 2404 eligible subjects, of whom $1748(72.7 \%)$ agreed to participate in the study: $839(48 \%)$ were men and $909(52 \%)$ women.

The mean temperature during the examinations was $21.5^{\circ} \mathrm{C}$ (standard deviation (SD) 1.18 ) and $99.5 \%$ of examinations were performed between 0800 and 1200 . There were no statistically significant differences in the number of examinations among the days of the week; $20.8 \%$ were performed in spring, $18.1 \%$ in summer, $35.4 \%$ in autumn, and $25.7 \%$ in winter.

LIPIDS

Total cholesterol had been measured in $63.3 \%$ of subjects in the previous year. Table 1 shows the distribution of lipids by ages and standardised by the world population.

Total cholesterol, LDL-c, and triglycerides increased significantly with age in women ( $r=0.40, r=0.37, r=0.34$ respectively), and also in men ( $r=0.13, r=0.14, r=0.09$ respectively). However, in men, a significant decrease in total cholesterol and LDL-c was observed in the 65-74 year decade compared with the previous age group.

No differences between sexes in total cholesterol were observed. The mean LDL-c was significantly higher in men between 25 to 44 years, similar between 45 to 64 , and higher in women between 65 to 74 years. Mean triglycerides were higher in men than in women in all age groups (table 1).

Levels of c-HDL scarcely changed with age either in men and women. In the latter, HDL-c levels were higher than those of men, regardless of age (table 1 ).

A slight increase in $\mathrm{Lp}$ (a) with age was observed in both sexes. This correlation was more marked in women $(r=0.20, \mathrm{p}<0.001)$ than in men $(r=0.11, \mathrm{p}=0.002)$ (table 1$)$.

\section{FIBRINOGEN}

Fibrinogen concentrations increase with age in men $(r=0.35, p<0.001)$. They decreased in women from the 25 to 34 to the 35 to 44 age group but later increase again $(r=0.29$, $\mathrm{p}<0.001)$. Values were somewhat higher in women than in men, although differences were not statistically significant between sexes in any age group (table 1).

\section{BLOOD PRESSURE}

The adult sleeve was used on $89.5 \%$, the youth sleeve on $6.9 \%$, and the obese on $3.6 \%$ of occasions. 
Table 1 Mean (SD) by 10 year age groups of total cholesterol (mmolll), HDL cholesterol (mmolll), LDL cholesterol (mmolll), triglycerides (mmoll/), lipoprotein (a) (Lp(a)) (g/l), and fibrinogen ( $g / l)$. Study of cardiovascular risk factor prevalence in Gerona, Spain 1995

\begin{tabular}{|c|c|c|c|c|c|c|c|c|}
\hline Men & $\begin{array}{l}25-34 \\
(n=130)\end{array}$ & $\begin{array}{l}35-44 \\
(n=159)\end{array}$ & $\begin{array}{l}45-54 \\
(n=160)\end{array}$ & $\begin{array}{l}55-64 \\
(n=183)\end{array}$ & $\begin{array}{l}65-74 \\
(n=170)\end{array}$ & $\begin{array}{l}\text { Population } \\
\text { mean } \\
25-74 \\
(n=802)\end{array}$ & $\begin{array}{l}\text { Standardised } \\
\text { mean }{ }^{\star} \\
25-74 \\
(n=802)\end{array}$ & $\begin{array}{l}\text { Standardised } \\
\text { mean }^{\star} \\
35-64 \\
(n=502)\end{array}$ \\
\hline Total cholesterol & $5.09(0.93)$ & $5.95(1.11)$ & $5.95(1.16)$ & $6.10(1.03)$ & $5.66(1.06)$ & $5.72(0.41)$ & 5.69 & 5.97 \\
\hline HDL cholesterol & $1.19(0.34)$ & $1.22(0.36)$ & $1.22(0.36)$ & $1.27(0.36)$ & $1.19(0.34)$ & $1.22(0.31)$ & 1.22 & 1.24 \\
\hline LDL cholesterol & $3.36(0.85)$ & $4.03(1.09)$ & $4.03(1.01)$ & $4.24(0.98)$ & $3.90(0.93)$ & $3.88(0.34)$ & 3.88 & 4.09 \\
\hline Triglycerides & $1.47(2.05)$ & $1.46(1.03)$ & $1.54(1.14)$ & $1.39(0.80)$ & $1.31(0.59)$ & $1.45(0.09)$ & 1.46 & 1.47 \\
\hline $\operatorname{Lp}(\mathrm{a}) \dagger$ & $0.18(0.03-1.90)$ & $0.20(0.03-2.00)$ & $0.20(0.03-1.60)$ & $0.24(0.03-2.10)$ & $0.27(0.03-2.10)$ & $0.22(0.03-2.10)$ & - & - \\
\hline Fibrinogen & $2.67(0.55)$ & $2.78(0.60)$ & $3.01(0.59)$ & $3.14(0.65)$ & $3.38(0.77)$ & $2.96(0.28)$ & 2.93 & 2.96 \\
\hline Women & $25-34(n=143)$ & $35-44(n=182)$ & $45-54(n=192)$ & $55-64(n=196)$ & $65-74(n=155)$ & $\begin{array}{l}\text { Population mean } \\
25-74 \\
(n=868)\end{array}$ & $\begin{array}{l}\text { Standardised } \\
\text { mean }^{\star} \\
25-74 \\
(n=868)\end{array}$ & $\begin{array}{l}\text { Standardised } \\
\text { mean } \\
35-64 \\
(n=570)\end{array}$ \\
\hline Total cholesterol & $5.02(0.93)$ & $5.33(0.96)$ & $5.95(1.24)$ & $6.13(1.14)$ & $6.44(1.06)$ & $5.66(0.59)$ & 5.61 & 5.74 \\
\hline HDL cholesterol & $1.37(0.36)$ & $1.37(0.34)$ & $1.55(0.39)$ & $1.37(0.39)$ & $1.50(0.39)$ & $1.47(0.05)$ & 1.47 & 1.47 \\
\hline LDL cholesterol & $3.15(0.78)$ & $3.47(0.88)$ & $3.93(1.16)$ & $4.14(1.06)$ & $4.34(0.96)$ & $3.72(0.49)$ & 3.67 & 3.80 \\
\hline Triglycerides & $0.93(0.47)$ & $0.91(0.41)$ & $1.04(0.58)$ & $1.22(0.58)$ & $1.32(0.62)$ & $1.07(0.18)$ & 1.04 & 1.04 \\
\hline $\operatorname{Lp}(\mathrm{a}) \dagger$ & $0.17(0.03-1.7)$ & $0.16(0.03-1.6)$ & $0.22(0.03-2.13)$ & $0.24(0.03-2.5)$ & $0.34(0.03-2.2)$ & $0.22(0.03-2.5)$ & - & - \\
\hline Fibrinogen & $3.00(0.65)$ & $2.88(0.55)$ & $3.10(0.54)$ & $3.28(0.61)$ & $3.47(0.67)$ & $3.11(0.24)$ & 3.09 & 3.06 \\
\hline
\end{tabular}

${ }^{\star}$ Standardised by the world population. $†$ Median (minimum, maximum) of distributions.

The standardised real hypertension prevalence for the world population was $27.7 \%$ in women from 25 to 74 years and $31.3 \%$ in men of the same age when participants with SBP $\geqslant 140 \mathrm{~mm} \mathrm{Hg}$ or DBP $\geqslant 90 \mathrm{~mm} \mathrm{Hg}$ or those who had received antihypertensive therapy in the two previous weeks were considered to be hypertensive (table 2). Only in $4.5 \%$ of women and $3.5 \%$ of men was this hypertension control- led. Drug treatment had been received in the previous two weeks by $15.3 \%$ of women and $37.6 \%$ of men; of these, BP was controlled in only $11.2 \%$ and $35.8 \%$, respectively (table 2 ).

The standardised prevalence in the 35 to 64 age group, considering the WHO-Monica criteria for hypertension (SBP values $\geqslant 160$ $\mathrm{mm} \mathrm{Hg}$ or DBP $\geqslant 95 \mathrm{~mm}$ or receiving antihypertensive therapy), was $15.6 \%$ in women and

Table 2 Prevalence of arterial hypertension by 10 year age groups according to criteria of the Foint National Committee of the United States $1993 .{ }^{11}$ Study of cardiovascular risk factor prevalence in Gerona, Spain 1995. Data shown as percentages

\begin{tabular}{|c|c|c|c|c|c|c|c|c|}
\hline Men & $\begin{array}{l}25-34 \\
(n=133)\end{array}$ & $\begin{array}{l}35-44 \\
(n=162)\end{array}$ & $\begin{array}{l}45-54 \\
(n=170)\end{array}$ & $\begin{array}{l}55-64 \\
(n=193)\end{array}$ & $\begin{array}{l}65-74 \\
(n=181)\end{array}$ & $\begin{array}{l}\text { Population } \\
\text { prevalence } \\
25-74 \\
(n=839)\end{array}$ & $\begin{array}{l}\text { Standardised } \\
\text { prevalence } \\
25-74 \\
(n=839)\end{array}$ & $\begin{array}{l}\text { Standardised } \\
\text { prevalence } \\
35-64 \\
(n=525)\end{array}$ \\
\hline Observed hypertension (1) & 9.2 & 18.5 & 38.0 & 49.3 & 63.9 & 38.3 & 29.7 & 33.4 \\
\hline Real hypertension (2) & 9.5 & 18.5 & 38.8 & 53.6 & 70.4 & 41.1 & 31.3 & 34.8 \\
\hline Treated hypertension (3) & 2.9 & 2.9 & 21.3 & 31.6 & 40.5 & 29.9 & 15.3 & 16.8 \\
\hline Controlled hypertension (4) & 2.9 & 0.0 & 2.0 & 8.2 & 9.5 & 6.9 & 3.5 & 2.8 \\
\hline Treated and controlled hypertension (5) & 100 & 0.0 & 7.7 & 24.1 & 22.4 & 23.5 & 35.8 & 9.0 \\
\hline Women & $\begin{array}{l}25-34 \\
(n=149)\end{array}$ & $\begin{array}{l}35-44 \\
(n=179)\end{array}$ & $\begin{array}{l}45-54 \\
(n=198)\end{array}$ & $\begin{array}{l}55-64 \\
(n=217)\end{array}$ & $\begin{array}{l}65-74 \\
(n=166)\end{array}$ & $\begin{array}{l}\text { Population } \\
\text { prevalence } \\
25-74 \\
(n=909)\end{array}$ & $\begin{array}{l}\text { Standardised } \\
\text { prevalence } \\
25-74 \\
(n=909)\end{array}$ & $\begin{array}{l}\text { Standardised } \\
\text { prevalence* }^{*} \\
35-64 \\
(n=594)\end{array}$ \\
\hline Observed hypertension (1) & 1.5 & 10.8 & 27.5 & 58.7 & 71.1 & 35.2 & 25.6 & 29.1 \\
\hline Real hypertension (2) & 1.5 & 10.8 & 30.8 & 62.6 & 79.1 & 38.2 & 27.7 & 31.3 \\
\hline Treated hypertension (3) & 35.3 & 41.7 & 35.1 & 36.4 & 41.4 & 38.4 & 37.6 & 37.9 \\
\hline Controlled hypertension (4) & 0.0 & 0.0 & 10.8 & 6.1 & 10.8 & 8.3 & 4.5 & 5.4 \\
\hline Treated and controlled hypertension (5) & 0.0 & 0.0 & 26.8 & 16.8 & 26.5 & 20.9 & 11.2 & 13.8 \\
\hline
\end{tabular}

* Standardised by the world population. $\mathrm{SBP}=$ systolic blood pressure; $\mathrm{DBP}=$ diastolic blood pressure. (1) SBP $\geqslant 140$ or DBP $\geqslant 90 ;(2) \mathrm{SBP} \geqslant 140$ or $\mathrm{DBP} \geqslant 90$ and/or drug treatment; (3) Percentage of hypertensives receiving treatment; (4) SBP <140 and/or DBP <90 in those drug treated among real hypertensives; (5) SBP <140 and/or $<90$ compared with treated hypertensives.

Table 3 Mean (SD) by 10 year age groups of blood pressure ( $\mathrm{mm} \mathrm{Hg),} \mathrm{systolic,} \mathrm{diastolic,} \mathrm{and} \mathrm{glycaemia} \mathrm{(mmol/l).} \mathrm{Study} \mathrm{of} \mathrm{cardiovascular} \mathrm{risk} \mathrm{factors}$ prevalence in Gerona, Spain 1995

\begin{tabular}{|c|c|c|c|c|c|c|c|c|}
\hline Men & $\begin{array}{l}25-34 \\
(n=133)\end{array}$ & $\begin{array}{l}35-44 \\
(n=162)\end{array}$ & $\begin{array}{l}45-54 \\
(n=170)\end{array}$ & $\begin{array}{l}55-64 \\
(n=193)\end{array}$ & $\begin{array}{l}65-74 \\
(n=181)\end{array}$ & $\begin{array}{l}\text { Population } \\
\text { mean } \\
25-74 \\
(n=839)\end{array}$ & $\begin{array}{l}\text { Standardised } \\
\text { mean }{ }^{\star} \\
25-74 \\
(n=839)\end{array}$ & $\begin{array}{l}\text { Standardised } \\
\text { mean }^{\star} \\
35-64 \\
(n=525)\end{array}$ \\
\hline Mean SBP & $121(12.3)$ & $122(12.3)$ & $133(18.9)$ & $141(39.4)$ & $146(18.5)$ & $131(11.3)$ & 129 & 131 \\
\hline Mean DBP & $72(8.9)$ & $77(10.2)$ & $81(11.8)$ & $81(10.1)$ & $80(9.8)$ & $78(11.2)$ & 78 & 80 \\
\hline Glycaemia & $5.41(1.16)$ & $5.64(0.87)$ & $5.80(1.09)$ & $6.30(1.91)$ & $6.19(1.72)$ & $5.80(0.40)$ & 5.75 & 5.86 \\
\hline Women & $\begin{array}{l}25-34 \\
(n=149)\end{array}$ & $\begin{array}{l}35-44 \\
(n=179)\end{array}$ & $\begin{array}{l}45-54 \\
(n=198)\end{array}$ & $\begin{array}{l}55-64 \\
(n=217)\end{array}$ & $\begin{array}{l}65-74 \\
(n=166)\end{array}$ & $\begin{array}{l}\text { Population } \\
\text { mean 25-74 } \\
(n=909)\end{array}$ & $\begin{array}{l}\text { Standardised } \\
\text { mean }^{\star} \\
25-74 \\
(n=909)\end{array}$ & $\begin{array}{l}\text { Standardised } \\
\text { mean }^{\star} \\
35-64 \\
(n=594)\end{array}$ \\
\hline Mean SBP & $110(11.6)$ & $115(14.8)$ & $127(16.2)$ & $142(18.0)$ & $148(17.6)$ & $126(15.8)$ & 125 & 128 \\
\hline Mean DBP & $64.4(7.3)$ & $70(10.7)$ & $76(10.7)$ & $82(10.5)$ & $82(9.9)$ & $75(15.6)$ & 74 & 77 \\
\hline Glycaemia & $5.13(0.11)$ & $5.29(0.54)$ & $5.52(1.24)$ & $6.14(3.70)$ & $5.97(1.55)$ & $5.52(0.46)$ & 5.47 & 5.58 \\
\hline
\end{tabular}

${ }^{\star}$ Standardised by the world population. Abbreviations as for table 2 . 
Table 4 Prevalence of smoking by 10 year age groups. Study of cardiovascular risk factor prevalence in Gerona, Spain 1995

\begin{tabular}{|c|c|c|c|c|c|c|c|c|}
\hline Men & $\begin{array}{l}25-34 \\
(n=133)\end{array}$ & $\begin{array}{l}35-44 \\
(n=162)\end{array}$ & $\begin{array}{l}45-54 \\
(n=170)\end{array}$ & $\begin{array}{l}55-64 \\
(n=193)\end{array}$ & $\begin{array}{l}65-74 \\
(n=181)\end{array}$ & $\begin{array}{l}\text { Population } \\
\text { prevalence } \\
25-74 \\
(n=839)\end{array}$ & $\begin{array}{l}\text { Standardised } \\
\text { prevalence } \\
25-74 \\
(n=839)\end{array}$ & $\begin{array}{l}\text { Standardised } \\
\text { prevalence } \\
35-64 \\
(n=525)\end{array}$ \\
\hline $\begin{array}{l}\text { Current smokers }(\%) \\
\text { Maximum consumption in current smokers } \dagger \\
\text { Ex-smokers }(\%) \ddagger\end{array}$ & $\begin{array}{l}39.1 \\
27(15) \\
37.3\end{array}$ & $\begin{array}{l}45.1 \\
24(15) \\
39.9\end{array}$ & $\begin{array}{l}30.5 \\
22(13) \\
48.8\end{array}$ & $\begin{array}{l}23.7 \\
30(16) \\
59.2\end{array}$ & $\begin{array}{l}15.3 \\
23(16) \\
57.1\end{array}$ & $\begin{array}{l}29.57 \\
25(2) \\
50.6\end{array}$ & $\begin{array}{l}33.8 \\
25 \\
45.9\end{array}$ & $\begin{array}{l}34.4 \\
24 \\
48.0\end{array}$ \\
\hline Women & $\begin{array}{l}25-34 \\
(n=149)\end{array}$ & $\begin{array}{l}35-44 \\
(n=179)\end{array}$ & $\begin{array}{l}45-54 \\
(n=198)\end{array}$ & $\begin{array}{l}55-64 \\
(n=217)\end{array}$ & $\begin{array}{l}65-74 \\
(n=166)\end{array}$ & $\begin{array}{l}\text { Population } \\
\text { prevalence } \\
25-74 \\
(n=909)\end{array}$ & $\begin{array}{l}\text { Standardised } \\
\text { prevalence }^{*} \\
25-74 \\
(n=909)\end{array}$ & $\begin{array}{l}\text { Standardised } \\
\text { prevalence }^{*} \\
35-64 \\
(n=594)\end{array}$ \\
\hline $\begin{array}{l}\text { Current smokers }(\%) \\
\text { Maximum consumption in current smokers } \dagger \\
\text { Ex-smokers }(\%) \ddagger\end{array}$ & $\begin{array}{l}45.6 \\
16.9 \\
22.7\end{array}$ & $\begin{array}{l}30.0 \\
20(13) \\
17.4\end{array}$ & $\begin{array}{l}8.6 \\
14(8) \\
4.1\end{array}$ & $\begin{array}{l}4.7 \\
15(6) \\
1.7\end{array}$ & $\begin{array}{l}1.3 \\
16(10) \\
2.6\end{array}$ & $\begin{array}{l}17.0 \\
17(2) \\
7.4\end{array}$ & $\begin{array}{l}22.7 \\
17 \\
11.9\end{array}$ & $\begin{array}{l}15.9 \\
17 \\
8.6\end{array}$ \\
\hline
\end{tabular}

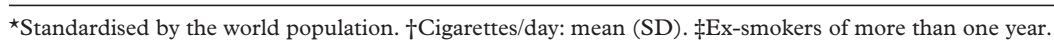

$15.7 \%$ in men. The hypertension was controlled in $15.9 \%$ of men and $59.5 \%$ of women.

$\mathrm{BP}$ levels increased with age in both men and women $(p<0.001)$ (table 3). Both SBP and DBP values were significantly higher in men than in women, except in the last two age decades studied (55-64 and 65-74 years) (table 3). It is important to note that $79.7 \%$ of subjects interviewed stated that their $\mathrm{BP}$ had been controlled at least once in the previous year.

DIABETES

Of the interviewees, $9.4 \%$ of men and $6.8 \%$ of women stated that they had been diagnosed of diabetes and were receiving corresponding dietetic, drug treatment or both at that time; in all, 3.9\% were taking oral antidiabetic medication and $1.3 \%$ were on injected insulin. Table 3 shows glycaemia distribution by age and sex.

\section{SMOKING}

Smoking prevalence of one or more cigarettes per day, standardised for the world population, was $33.8 \%$ in men and $22.7 \%$ in women in all the age groups studied. The female smoker rate $(45.6 \%)$ in the $25-34$ year age group was greater than that of any other age group, both for men and women (table 4). Consumption was much greater in women in the 25 to 44 group than in older age groups (table 5).

Mean maximum daily cigarette consumption was 17.4 (SD 2.3) in female smokers and 24.4
(SD 2.4) in male smokers. The proportion of ex-smokers increased with age in men, reaching $59.2 \%$ between 55 and 64 years of age. The overall proportion of male ex-smokers was $45.9 \%$ and $11.9 \%$ for women (table 4 ).

\section{OVERWEIGHT AND OBESITY}

BMI tended to increase in both sexes up to the age of 64 (table 5). In the first two age decades studied, BMI was observed to be higher in men than in women $(p<0.0001)$. In the $45-54$ decade, values were similar; however, a marked overweight in women compared with men was observed in the last two decades (table 5). It is noteworthy that $19 \%$ of participants $(17.3 \%$ men, $19.6 \%$ women) presented with $\mathrm{BMI}>30$ $\mathrm{kg} / \mathrm{m}^{2}$, and in $3.6 \% \mathrm{BMI}$ was over $35 \mathrm{~kg} / \mathrm{m}^{2}$.

Whereas results obtained in upper arm perimeter or arm skin fold parallel those of BMI, the waist/hip ratio tended to increase with age in both sexes. The correlation between the waist/hip ratio and LDL was $0.2, \mathrm{p}<0.001$.

\section{ELECTROCARDIOGRAPHIC PREVALENCE OF} DEFINITE AND POSSIBLE AMI

Definite or possible AMI were found in 33 participants (1.8\%): 21 men $(2.6 \%)$ and 12 women $(1.4 \%)$.

ANGINA PREVALENCE

Table 6 shows angina prevalence rates by sex and age groups. A total of 74 participants had

Table 5 Mean (SD) of anthropometric measurements and daily energy expenditure in leisure time physical activity by 10 year age groups. Study of cardiovascular risk factor prevalence in Gerona, Spain 1995

\begin{tabular}{|c|c|c|c|c|c|c|c|c|}
\hline Men & $\begin{array}{l}25-34 \\
(n=133)\end{array}$ & $\begin{array}{l}35-44 \\
(n=162)\end{array}$ & $\begin{array}{l}45-54 \\
(n=170)\end{array}$ & $\begin{array}{l}55-64 \\
(n=193)\end{array}$ & $\begin{array}{l}65-74 \\
(n=181)\end{array}$ & $\begin{array}{l}\text { Population } \\
\text { mean } \\
25-74 \\
(n=839)\end{array}$ & $\begin{array}{l}\text { Standardised } \\
\text { mean } \\
25-74 \\
(n=839)\end{array}$ & $\begin{array}{l}\text { Standardised } \\
\text { mean } \\
35-64 \\
(n=525)\end{array}$ \\
\hline Body mass index $\left(\mathrm{kg} / \mathrm{m}^{2}\right)$ & $25(3)$ & $26(3)$ & $27(3)$ & $27(5)$ & $27(4)$ & $26(1)$ & 26 & 26 \\
\hline Right tricipital skinfold (mm) & $10(5)$ & $10(5)$ & $11(6)$ & $11(6)$ & $9(4)$ & $10(1)$ & 10 & 11 \\
\hline Left tricipital skinfold (mm) & $10(5)$ & $10(5)$ & $11(6)$ & $11(6)$ & $9(4)$ & $10(1)$ & 10 & 11 \\
\hline Arm perimeter $(\mathrm{cm})$ & $30(2)$ & $30(2)$ & $31(3)$ & $30(3)$ & $29(3)$ & $30(1)$ & 30 & 31 \\
\hline Waist/hip ratio & $0.87(0.07)$ & $0.90(0.07)$ & $0.93(0.07)$ & $0.94(0.07)$ & $0.96(0.07)$ & $0.91(0.03)$ & 0.91 & 0.92 \\
\hline \multirow[t]{3}{*}{ Physical activity $(\mathrm{kcal} / \mathrm{d})$} & $325.3(264.3)$ & $328.4(337.9)$ & $271.4(303.3)$ & $398.7(402.2)$ & $400.3(336.0)$ & $345.0(333.5)$ & 333.7 & 326.7 \\
\hline & & & & & & $\begin{array}{l}\text { Population } \\
\text { mean }\end{array}$ & $\begin{array}{l}\text { Standardised } \\
\text { mean }\end{array}$ & $\begin{array}{l}\text { Standardised } \\
\text { mean }\end{array}$ \\
\hline & $\begin{array}{l}25-34 \\
(n=149)\end{array}$ & $\begin{array}{l}35-44 \\
(n=179)\end{array}$ & $\begin{array}{l}45-54 \\
(n=198)\end{array}$ & $\begin{array}{l}55-64 \\
(n=217)\end{array}$ & $\begin{array}{l}65-74 \\
(n=166)\end{array}$ & $\begin{array}{l}25-74 \\
(n=909)\end{array}$ & $\begin{array}{l}25-74 \\
(n=909)\end{array}$ & $\begin{array}{l}35-64 \\
(n=594)\end{array}$ \\
\hline Body mass index $\left(\mathrm{kg} / \mathrm{m}^{2}\right)$ & $23(3)$ & $25(5)$ & $27(4)$ & $28(5)$ & $28(5)$ & $26(2)$ & 26 & 27 \\
\hline Right tricipital skinfold (mm) & $16(6)$ & $19(7)$ & $19(7)$ & $20(8)$ & $19(7)$ & $18(1)$ & 18 & 19 \\
\hline Left tricipital skinfold (mm) & $16(7)$ & $19(7)$ & $20(7)$ & $20(8)$ & $19(7)$ & $19(1)$ & 19 & 20 \\
\hline Arm perimeter $(\mathrm{cm})$ & $28(4)$ & $29(3)$ & $30(3)$ & $30(3)$ & $30(4)$ & $29(1)$ & 29 & 30 \\
\hline Waist/hip ratio & $0.78(0.09)$ & $0.80(0.07)$ & $0.82(0.08)$ & $0.85(0.08)$ & $0.87(0.07)$ & $0.81(0.03)$ & 0.81 & 0.82 \\
\hline Physical activity (kcal/d) & $212.8(183.6)$ & $261.1(398.5)$ & $181.3(191.7)$ & $194.9(197.6)$ & $207.2(221.8)$ & $211.5(238.6)$ & 214.0 & 215.7 \\
\hline
\end{tabular}

^Standardised by the world population. 
Table 6 Prevalence of angina pectoris by 10 year age groups. Study of cardiovascular risk factor prevalence in Gerona, 1995. Data shown as percentages

\begin{tabular}{|c|c|c|c|c|c|c|c|c|}
\hline Men & $\begin{array}{l}25-34 \\
(n=133)\end{array}$ & $\begin{array}{l}35-44 \\
(n=162)\end{array}$ & $\begin{array}{l}45-54 \\
(n=170)\end{array}$ & $\begin{array}{l}55-64 \\
(n=193)\end{array}$ & $\begin{array}{l}65-74 \\
(n=181)\end{array}$ & $\begin{array}{l}\text { Population } \\
\text { prevalence } \\
25-74 \\
(n=839)\end{array}$ & $\begin{array}{l}\text { Standardised } \\
\text { prevalence } \\
25-74(n=839)\end{array}$ & $\begin{array}{l}\text { Standardised } \\
\text { prevalence } \\
35-64(n=525)\end{array}$ \\
\hline Definite angina & 1.3 & 1.8 & 1.6 & 4.5 & 6.9 & 3.0 & 2.6 & 2.5 \\
\hline Possible angina & 0 & 0 & 0.9 & 4.3 & 7.2 & 2.1 & 1.6 & 1.4 \\
\hline & & & & & & $\begin{array}{l}\text { Population } \\
\text { prevalence }\end{array}$ & $\begin{array}{l}\text { Standardised } \\
\text { prevalence* }\end{array}$ & $\begin{array}{l}\text { Standardised } \\
\text { prevalence }\end{array}$ \\
\hline Women & $\begin{array}{l}25-34 \\
(n=149)\end{array}$ & $\begin{array}{l}35-44 \\
(n=179)\end{array}$ & $\begin{array}{l}45-54 \\
(n=198)\end{array}$ & $\begin{array}{l}55-64 \\
(n=217)\end{array}$ & $\begin{array}{l}65-74 \\
(n=166)\end{array}$ & $\begin{array}{l}25-74 \\
(n=909)\end{array}$ & $\begin{array}{l}25-74 \\
(n=909)\end{array}$ & $\begin{array}{l}35-64 \\
(n=594)\end{array}$ \\
\hline Definite angina & 0 & 1.3 & 3.7 & 5.9 & 13.4 & 3.9 & 3.4 & 3.3 \\
\hline Possible angina & 0 & 0 & 0 & 1.4 & 3.3 & 0.7 & 0.6 & 0.4 \\
\hline
\end{tabular}

^Standardised by the world population.

definite and 29 possible angina. Angina prevalence also increased steeply with age. Standardised prevalence rates of definite angina were $2.6 \%$ in men and $3.4 \%$ in women aged $25-74$ years. When definite or possible angina was considered, these rates ranged from $4.2 \%$ in men to $4.0 \%$ in women.

LEISURE TIME PHYSICAL ACTIVITY

Leisure time physical activity was greater in men than in women (table 5). In men, physical activity tended to decrease with age between 25 and 55 years, an increase in physical activity was observed thereafter. In women, a slight decrease in physical activity was observed with age.

FAMILY HISTORY OF ISCHAEMIC CORONARY DISEASE

A family history of ICD was observed in $16.5 \%$ of participants, with no statistically significant differences between sexes $(15.1 \%$ in men and $17.7 \%$ in women).

\section{Discussion}

Over 40 years ago, researchers of the Framingham study ${ }^{16}$ coined the term CRF and related its presence to the incidence and mortality of ICD. ${ }^{17}$ Later clinical trials on the role of these factors showed that they could be modified ${ }^{18} 19$ and that such modifications resulted in a decrease in morbidity and mortality of ICD. ${ }^{20}$ This evidence and the low efficiency on the public health level of the preventive approach
KEY POINTS

- Despite low incidence and death rates of myocardial infarction, Gerona, Spain, has a relatively high cardiovascular risk factor prevalence.

- Physical activity might confer part of the protection that compensates the prevalence observed.

- The factors that protect for coronary heart disease, such as the interaction between environmental, particularly diet and physical activity, and genetic characteristics of the population, remain to be elucidated.

of "high risk" necessitate the study of the prevalence of CRFs in wide geographical areas to organise the preventive methods provided on a populational scale.

A study conducted in a Spanish working population assessed the relation between coronary risk factors and the incidence at 20 years of ICD and observed that both hypercholesterolaemia ( $\geqslant 6.47 \mathrm{mmol} / \mathrm{l})$ and systolic hypertension $(\geqslant 160 \mathrm{~mm} \mathrm{Hg}$ ), smoking and hyperglycaemia $(>66.96 \mathrm{mmol} / \mathrm{l})$ were associated with a greater risk of myocardial infarction. ${ }^{21}$ In our environment, the results of this study confirm the high prevalence of some classic CRF already observed in other studies conducted in Spain a few years ago. ${ }^{3-5}$

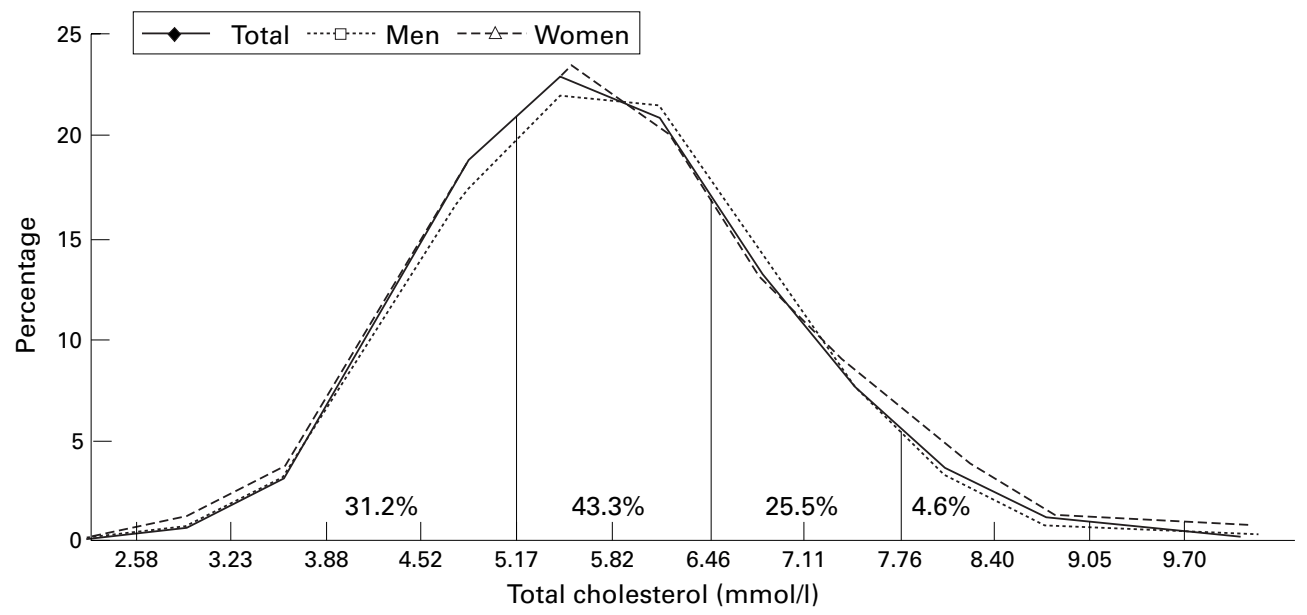

Figure 1 Distribution of total cholesterol. Study of cardiovascular risk factors in Gerona, Spain 1995. 
HYPERTENSION, LIPIDS, FIBRINOGEN, AND SMOKING

The high prevalence of BP could be attributable to the recent modification of limits for the definition of BP (SBT $\geqslant 140 \mathrm{~mm} \mathrm{Hg}$, DBT $\geqslant 90)$. At the time of carrying out the field work, the Joint National Committee on detection, evaluation and treatment of high blood pressure ${ }^{11}$ had just been published, and therefore the majority of primary health care centres were probably applying the previous criterion (SBT $\geqslant 160$, DBT $\geqslant 95) .{ }^{22}$ The low prevalence of BP treatment and control could be attributed, at least in part, to the same causes. When the old criterion are applied, results coincide with those of most Spanish studies, ${ }^{3-523}$ although they are higher than those of the MONICA Catalunya conducted in 1986 in the Barcelona area. ${ }^{24} \mathrm{BP}$ levels both in men and women increase with age, which had already been established by previous studies. . $^{3-5}$

The high prevalence of hypercholesterolaemia is noteworthy (approximately $68 \%$ of men and $67 \%$ of women of $25-74$ years present total cholesterol concentrations above $5.17 \mathrm{mmol} / \mathrm{l}$ ) (fig 1). Despite the hormone changes in the perimenopausal periods in women (45-54 years), no different patterns were observed in the distribution of total cholesterol means in men and women in these age groups. Total cholesterol was similar to that obtained in Spain $^{424}$ although all these comparisons should be made with caution as the studies were conducted at different times and there were differences in laboratory methods.

HDL cholesterol concentration was high compared with other international studies ${ }^{25}$ but somewhat lower than that obtained in Castilla la Mancha. ${ }^{4}$

An increase with age was observed for $\operatorname{Lp}(a)$, which despite being significant, cannot be considered clinically relevant. This finding concurs with those of other authors, ${ }^{26}$ although its biological interpretation is complicated based on current knowledge.

An increase with age was also observed in the case of fibrinogen. However, the decrease in women of 35-44 compared with those of 25 to 34 should be emphasised. This could be attributed to smoking in the younger age group, a fact that has been observed in other studies ${ }^{27}$ Mean fibrinogen among female smokers in the 25-44 group was $3.03 \mathrm{~g} / 1$ (SD 0.59) and 2.87 $(\mathrm{SD} 0.58) \mathrm{g} / \mathrm{l}$ in female non-smokers $(\mathrm{p}=0.03)$.

With respect to smoking, the great increase in women from 25 to 34 is surprising, surpassing that of men of any age; this coincides with all the studies recently conducted in Spain. ${ }^{3-6}$ Methods for stopping smoking should therefore be directed towards prevention in more affected groups.

ANGINA AND MYOCARDIAL INFARCTION

As corresponds to a low incidence area, a prevalence of angina lower than in Iceland, Finland and similar to Italy was observed..$^{28-30}$ Similarly, the proportion of participants with a definite or possible AMI was also low. Interestingly, women showed a greater prevalence of definite angina than men, which concurs with most studies. An explanation for this fact, as suggested by some authors, may be related to the different patterns of coronary heart disease manifestations between sexes: myocardial infarction and sudden death is more likely in men, while angina pectoris in women is more frequently uncomplicated. ${ }^{31}$

\section{OVERWEIGHT}

Overweight and BMI distribution follow a pattern that can practically be superimposed on all the Spanish studies conducted..$^{3-5}$ Marked obesity (BMI >30) implies a high risk of a coronary event independently of the other variables in southern Europe, ${ }^{32}$ and appears in $18.8 \%$ of all men and women in the present study (24-74 years).

Given that the material required for early detection and diagnosis is accessible from any field in primary health care, knowledge and control of overweight should be one of the main objectives of intervention. The mean of arm skin fold estimations increases with age in women, which may indicate that the increase in their BMI seems to be at the expense of adipose tissue.

\section{HIGH PREVALENCE OF CRF AND LOW AMI} INCIDENCE

It is important to point out that the high prevalence of CRF in our population contrasts with the low incidence of AMI (cumulated incidence per 100000 inhabitants, standardised for age, in the 25-74 age group 207.5 in men and 48.5 in women). ${ }^{2}$ If the results obtained in our population are compared with those of international studies conducted in populations with higher AMI incidence and death rates than those of the area presented here ${ }^{24} 3334$ it can be seen that, by age groups and sex, the total cholesterol, arterial pressure, smoking, and obesity in Gerona are lower than those of Nord-Karelia, Finland (fig 2). They are, however, higher than those of Minnesota, USA, where the AMI cumulated incidence in recent years was 915 per 100000 inhabitants in men and 165 in women (five and four times higher than ours, respectively), ${ }^{34}$ and 613 per 100000 inhabitants in men and 203 in women (three and four times higher than ours), ${ }^{33}$ respectively. Physical activity was somewhat higher in Gerona (table 5) than in Minnesota $(298 \mathrm{kcal} /$ day in men and $186 \mathrm{kcal} /$ day in women aged 25 to 74$)^{33}$ and might explain a small part of the different AMI incidence favouring Spain.

However, to account for this paradox, the fact that we are in a latency period between an increase in CRF and the rise in incidence and death rates by ICD cannot be ruled out although it seems unlikely in light of the absence of any age cohort effect demonstrated in the different age groups in Spain. ${ }^{35}$ Furthermore, in the Manresa study, ${ }^{21} 20$ years ago a relatively high prevalence of risk factors was observed that should be reflected in a higher incidence or mortality from ICD at present than observed after this follow up. Finally, the trends in ICD death rates have been decreasing since $1976 .{ }^{1}$ 
A
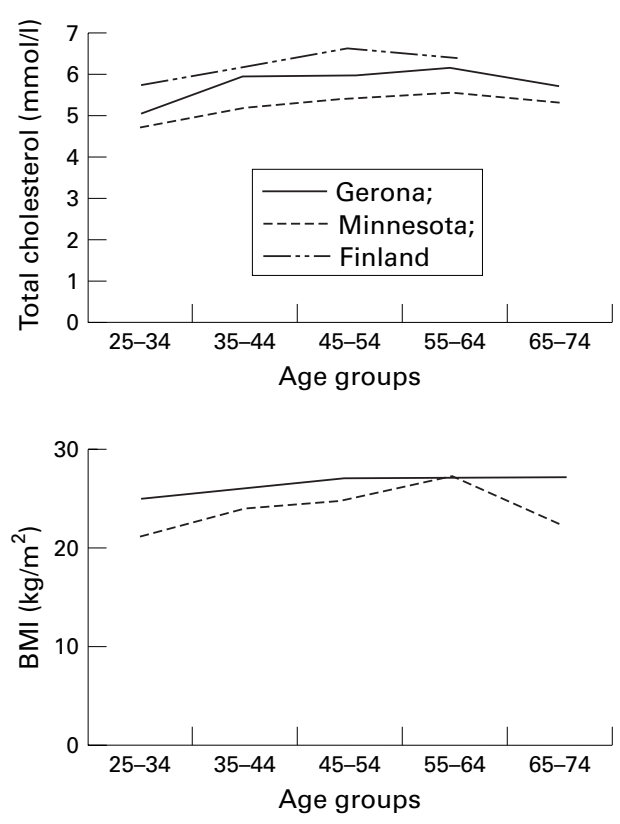

B
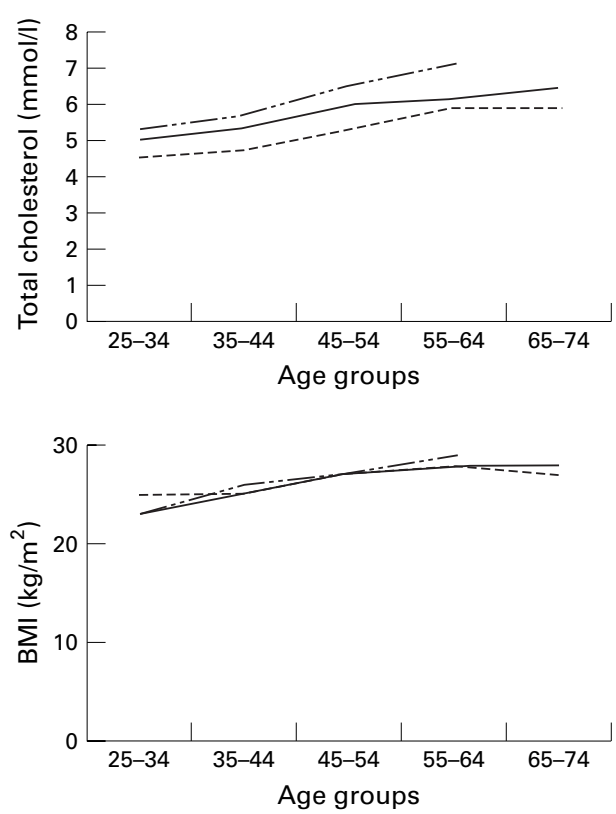
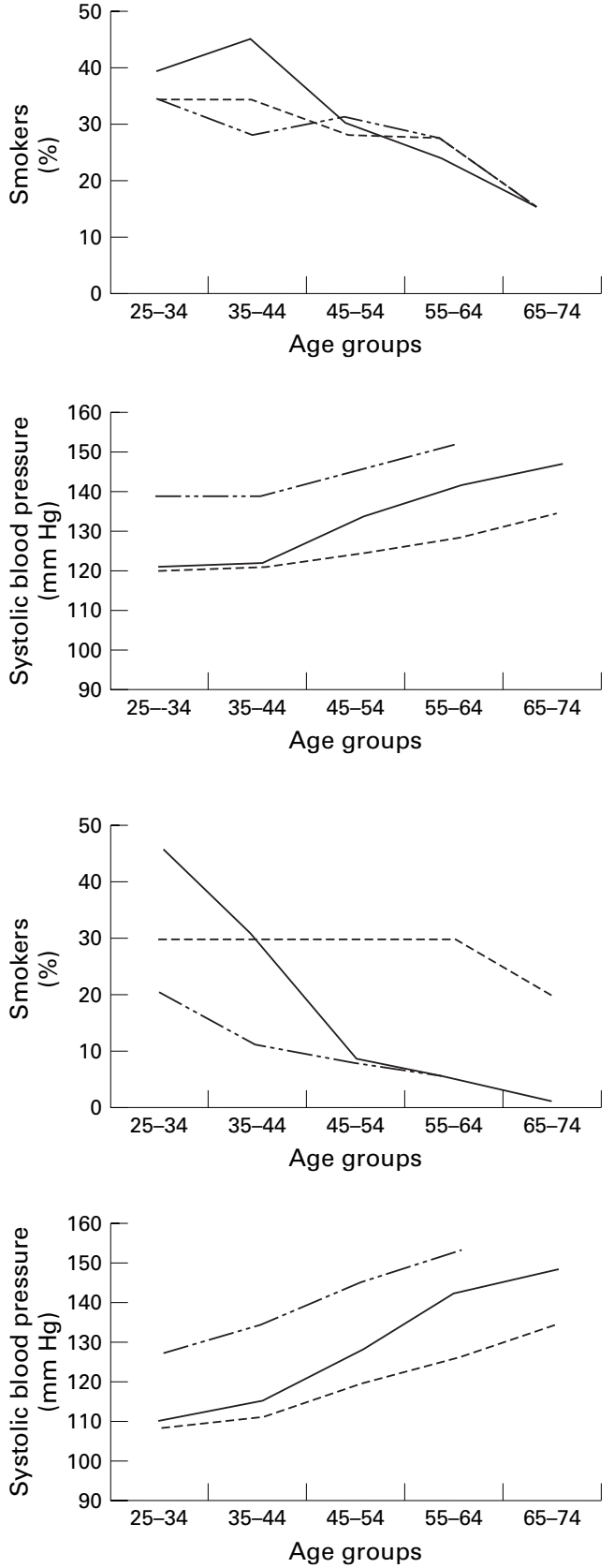

Figure 2 Mean or prevalence of different cardiovascular risk factor in men $(A)$ and women $(B)$ in different populations: Gerona (1995), Minnesota (1985-90 ${ }^{33}$ and Finland (1984-86). ${ }^{24}$ Standardised cumulated incidence of acute myocardial infarction was 207/100 000 in men and 48/100 000 in women aged 25-74 years in 1990-92 in Gerona, ${ }^{2}$ 613/100 000 in men and 203/100 000 in women aged 25-74 years in 1985-90 in Minnesota, ${ }^{33}$ and 915/100 000 in men and $165 / 100000$ in women aged $35-64$ years in 1985-87 in Finland. ${ }^{34}$

The "French paradox" (that is, apparent compatibility of a high fat diet with a low incidence of coronary atherosclerosis) ${ }^{36}$ could be extended to the paradoxical coexistence of high CRF prevalence and low AMI incidence and death rates found in our Southern Europe Mediterranean area. Besides dietary factors (wine, vegetable, and fruit consumption have been claimed to be in part responsible for the French paradox ${ }^{37}$ ), another explanation is that unconsidered or unknown factors exist in populations of this European area that may produce greater resistance to the physiopathological mechanisms of arteriosclerosis. It is reasonable to direct future research towards the study of protective factors such as diet, physical activity or their interaction with genetic characteristics of the population.

STUDY CHARACTERISTICS

It is important to emphasise the high participation of the study population $(72.7 \%)$. The results obtained are, therefore, representative of the area under study (Gerona) although, bearing in mind the possible variability among autonomous communities, generalisation of these data regarding the rest of Spain should be made with caution. However, results of other surveys conducted in Spain suggest that 
minimal differences are to be expected among Spanish regions.

Standardised methods when available, were used for measurements, and results presented in such a form for easy comparison with other international studies.

CLINICAL AND PUBLIC HEALTH IMPLICATIONS The prevalence of classic CRF in Gerona is relatively high. Despite the known low incidence and death rates of AMI in that area, it seems reasonable to promote measures for their control according to current recommendations. On the other hand, this paradoxical situation offers new opportunities for exploring the existence of unknown or unmeasured factors that might be protecting the Gerona population (and maybe other Southern European Mediterranean regions) from ICD. In light of comparative results, and apart from dietary habits that have been previously suggested, physical activity is a promising candidate factor to be analysed in detail. Furthermore, the interaction between genetic characteristics and environment should not be disregarded either. Deeper insight into these issues in international comparative studies may provide information relevant to ICD prevention and control.

The authors appreciate the English revision made by Ms Christine O'Hara and are grateful to Josep Maria Manresa and Oriol Codina for their collaboration in statistical analyses and to Montserrat Capdevila, Isabel Cateura, Isabel Sole, Angeles Montserrat Capdevila, Isabel Cateura, Isabel Sole, Angeles Gemma Hidalgo, and Cristina Costa for field work. We thank Gemma Hidalgo, and Cristina Costa for field work. We thank centres, hospitals, and town halls of the following cities for their centres, hospitals, and town halls of the following cities for their
cooperation: Agullana, Amer, Arbucies, Blanes, Calonge, cooperation: Agullana, Amer, Arbucies, Blanes, Calonge, Salt, Lloret de Mar, Mont-ras, Olot, Palafrugell, Porqueres, Banyoles, Riudellots de la Selva, Roses, Sant Feliu de Guixols, Sant Feliu de Pallerols, La Vall d' en B as, Sant Feliu de Buixalleu, Hostalrich, Santa Cristina d'Aro, Verges, Vilademuls, Bascara, Llan,ca, Oix, Bescano, Llagostera, Montagut, Cassa de la Selva, Cellera de Ter, Sant Pere Pescador, Olot, and Les Planes d'Hostoles.

REGICOR Investigators: C Ponsati, M Vicente, F Monzón(Hospital Comarcal de Figueres); J Bisbe, P Cortés, A Agustí, M Barcons (Hospital Comarcal Sant Jaume d'Olot); N Constans, R Massa, M Vendrell (Hospital Comarcal de La Selva); F Bassó, A Masabeu, J M Inoriza (Hospital Comarcal de Palamós); C A Masabeu, J M Inoriza (Hospital Comarcal de Palamós); C pital Provincial de Santa Caterina); X Albert, R Masiá, J Sala, L pital Provincial de Santa Caterina); X Albert, R Masiá, J Sala, L Gavalda (Hospital Josep Trueta de Girona); C Aubó, M Bosch, M Cardona, O Codina, M I Covas, R Elosua, M Gil, J M Man-
resa, J Marrugat, S Martín, M Pavesi, A Pena, G Pérez, P Roset, resa, J Marrugat, S Martín, M Pavesi, A Pena, G Pérez, P Ro

Funding: the present work was funded by grant FIS 94/0539 from the Fondo de Investigación Sanitaria and supported by grant CIRIT 1995/SGR/00167.

grant CIRIT 1995/SGR/0016

1 Olalla MT, Almazán J, Sierra MJ, et al. Mortalidad por enfermedad isquémica del corazón. Boletín Epidemiológico Semanal 1997;22:177-88.

2 Pérez G, Pena A, Sala J, et al. Acute myocardial infarction case fatality, incidence and mortality rates in a population
registry in the province of Gerona, Spain, 1990 to 1992 . Int registry in the province of Ger
7 Epidemiol 1998;27;599-604.

3 Banegas JR, Villar F, Pérez C, et al. Estudio Epidemiológico de los Factores de Riesgo Cardiovascular en la población española de 35 a 64 años. Rev Sanid Hig Publica (Madr) $1993 ; 67: 419-45$.

4 Segura A, de Mateo S, Gutierrez J. Epidemiología de los Factores de Riesgo Cardiovascular en un área rural de la región de Castilla la Mancha. Revista Latina de Cardiología 1986;8:377-85

5 Rodriguez Pérez JC, Calonge Ramirez S, et al. Prevalencia de los factores de riesgo de cardiopatía isquémica en la isle de Lanzarote. Med Clin (Barc) 1993;101:45-50

6 Martinez MA, Bueno A, Fernandez MA, et al. Prevalencia de factores de riesgo cardiovascular en población laboral. Med Clin (Barc) 1995;105:321-6.

7 Institut d'Estadística de Catalunya. Cens de població 1991. Barcelona: Institut d'Estadística de Catalunya, 1992.

8 Prineas RJ, Crow RS, Blackburn H. The Minnesota code. Manual of electrocardiographic Findings. Boston: John Wright, 1982 .
9 Covas MI, Martí S, Sentí M, et al. Evaluación de un método inmunoturbidimétrico para la determinación de la concentración sérica de lipoproteina(a). Clínica e Investigación en Arteriosclerosis 1995;8:15-20.

10 World Health Organisation. MONICA manual. Geneva: World Health Organisation, 1992

11 Joint National Committe on detection, evaluation and treatment of high blood pressure. The fifth report of the Joint National Committe on detection, evaluation and treatment of high blood pressure (JNC V). Arch Intern Med 1993;153: 154-83.

12 Rose GA, Blackburn H, Gillum RF, et al. Cardiovascular survey methods. Geneva: World Health Organization, 1982.

13 Taylor HL, Jacobs DR, Schucker B, et al. A questionnaire for the assessment of leisure time physical activities. $\mathcal{F}$ Chron Dis 1978;31:741-55.

14 Elosua R, Marrugat J, Molina L, et al. Validation of the Minnesota leisure time physical activity questionnaire Minnesota leisure time physical activity questionnaire
among Spanish men. Am $\mathcal{f}$ Epidemiol 1994;139:1192-209.

15 Waterhouse JAH, Muir C, Correa P, et al. Cancer incidence in five continents. Lyon: IARC Scientific Publications no 15, 1976: 456.

16 Kannel WB, Gordon T. The Framingham study. An epidemiologic investigation of cardiovascular disease. Section 30. Some characteristics related to the incidence of cardiovascular disease and death: 18-year follow-up. Publication 74-599. Washington DC: United States Government Printing Office, 1974.

17 Kannel WB. Factores de riesgo en la enfermedad coronaria: experiencia del seguimiento durante tres decades del estudio Framingham. Hipertension y Arteriosclerosis 1989;1:77-86.

18 Lindblad U, Rastam L, Ryden L, et al. Control of blood pressure and risk of first acute myocardial infarction: Ska-
raborg hypertension project. BMF 1994;308:681-6.

19 Law MR, Wald NJ, Thompson SG. By how much and how quickly does reduction in serum cholesterol concentration quickly does reduction in serum cholesterol concentration
lower risk of ischaemic heart disease. BMF 1994;308:36773.

20 Muldoon MF, Manuck SD, Matthews KA. Lowering cholesterol concentrations and mortality: a quantitative review of primary prevention trials. BMF 1990;301:309-14.

21 Tomás-Abadal L, Varas-Lorenzo C, Bernades-Bernat E, et al. Coronary risk factors and a 20 -year incidence of coronary heart disease and mortality in a Mediterranean industrial population. The Manresa study, Spain. Eur Heart f 1994;15:1028-36.

22 Liga Española pare la lucha contra la Hipertensión arterial. Consenso para el control de la hipertensión arterial en

23 Tresserras R, Pardell H. Prevalencia e importancia sanitaria de la hipertension arterial. Ann Med Intern (Madrid) 1990; 7:1-6.

24 The WHO MONICA Project. Geographical variation in the major risk factors of coronary heart disease in men and women aged 35-64 years. World Health Stat $Q$ 1988;41: 115-40.

25 Rosseneu M, Fruchart JC, Bard JM, et al. Plasma apolipoprotein concentrations in young adults with a parental history of premature coronary - heart disease and in control subjects. The EARS study. European Atherosclerosis Research Group. Circulation 1994;89:1967-73.

26 Jenner JL, Ordovas JM, Lamon-Fava S, et al. Effects of age, sex and menopausal status plasma lipoprotein (a) levels. The Framingham Offspring Study. Circulation 1993;87: 1135-41.

27 Meade TW. Epidemiology of atheroma, thrombosis and coronary heart disease. In: Born Gustav VR, Schwartz CJ, eds. New horizons in coronary heart disease. Texas: Current Science, 1993 .

28 Sigurdsson E, Thorggeirsson G, Siggvaldason H, et al. Prevalence of coronary heart disease in Icelandic men, 1968-1986. The Reykjavik study. Eur Heart $\mathcal{F}$ 1993;14: 584-91

29 Krogh V, Trevisan M, Panico S, et al. Prevalence and correlates of angina pectoris in the Italian nine communities study. Epidemiology 1991;2:26-32

30 Reunanen A, Aromaa A, Pyorola K, et al. The social insurance institution's coronary heart disease study. Baseline data and 5-year mortality experience. Acta Med Scand 1983;673 (suppl): 1-120

31 Lerner DJ, Kannel WB. Patterns of coronary heart disease morbidity and mortality in the sexes: a 26-year follow-up of the Framingham population. Am Heart f 1986;111:383-90.

32 ERICA Research Group. Prediction of coronary heart disease in Europe. The second report of the WHO-ERICA disease in Europe. The second report

33 McGovern PG, Pankow JS, Shahar E, et al. Recent trends in acute coronary heart disease mortality, morbidity, medical care, and risk factors. The Minnesota Heart Survey Investigators. N Engl F Med 1996;334:884-90.

34 Tunstall-Pedoe H, Kuulasmaa K, Amouyel P, et al. Myocardial infarction and coronary deaths in the World Health Organization MONICA Project. Circulation 1994;90:583612 .

35 Banegas JR, Alberdi JC, Rodríguez-Artalejo F, et al. Análisis edad-período-cohorte de la mortalidad por cardiopatía isquémica en España. 1965-1985. Gac Sanit 1992;6:97104.

36 Artaud-Wild SM, Connor SL, Sexton G, et al. Differences in coronary mortality can be explained by differences in cholesterol and saturated fat intakes in 40 countries but not in France and Finland. Circulation 1993;88:2771-9.

37 Renaud S, de Lorgeril M. Wine, alcohol, platelets, and the French paradox for coronary heart disease. Lancet
1992;339:1523-6. 